Olgu Sunumu / Case Report

\title{
Prematüre ovaryen yetmezlik ve 46,X,del(X)(q21)
}

\section{Premature ovarian failure and 46,X,del(X)(q21)}

\author{
Nurten Kara ${ }^{a}$, Şengul Tural*a, Gülsen Okten ${ }^{a}$, İdris Kocak ${ }^{b}$, Akın Tekcan ${ }^{a}$ \\ a Ondokuz Mayıs Üniversitesi, Tıp Fakültesi, Tıbbi Biyoloji Anabilim Dall, Tıbbi Genetik Bilim Dall, Samsun, Türkiye \\ ${ }^{b}$ Ondokuz Mayıs Üniversitesi, Tıp Fakültesi, Kadın Hastalıklarl ve Doğum Anabilim Dalı, Samsun, Türkiye
}

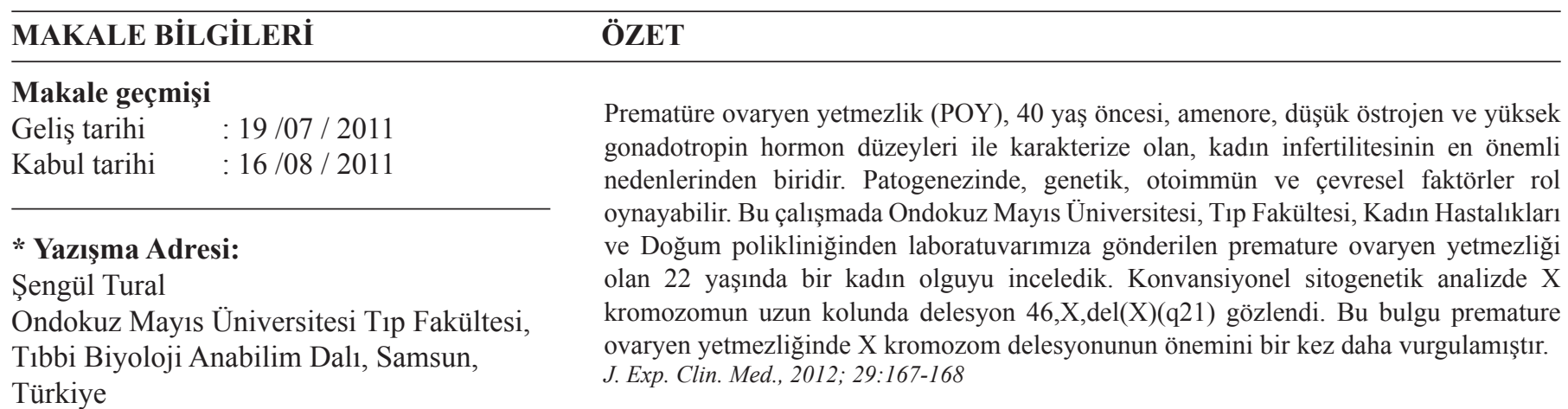

e-posta: stural@omu.edu.tr

\section{Anahtar Kelimeler:}

Premature ovaryen yetmezliği,

$\mathrm{X}$ kromozom delesyonu

Amenore

Sitogenetik

Kadın infertilitesi

Kromozom anomalisi

Key words:

Premature ovarian failure

$\mathrm{X}$ chromosome deletion

Amenorrhea

Cytogenetics

Female infertility

Chromosomal aberration

\begin{abstract}
Premature ovarian failure (POF) is a common cause of infertility in women, and is characterised by amenorrhoea, hypo-oestrogenism and elevated gonadotrophin levels in women under the age of 40 . Genetic, autoimmune and the environmental factors play a role in the pathogenesis. In this study, we investigated a 22 year-old woman having premature ovarian failure, referred to our laboratuary from Ondokuz Mayıs University Gynecology and Obstetrics polyclinic. In conventional cytogenetic analysis, a deletion was observed in the long arm of the $X$ chromosome $46, X, \operatorname{del}(X)(q 21)$. This finding was emphasised once again the significance of $\mathrm{X}$ chromosome deletions in the premature ovarian failure.

J. Exp. Clin. Med., 2012; 29:167-168
\end{abstract}

\section{Giriş}

Prematüre ovaryen yetmezliği (POY), 40 yaşından önce gözlenen, 6 aydan fazla mens olamama, artmış gonodotropinler ve $40 \mathrm{mlU} / \mathrm{ml}$ 'den yüksek serum FSH düzeyi ile tanımlanmaktadır (Coulam ve ark., 1986; Vegetti ve ark., 2000). POY; 30 yaş öncesi kadınlarda 1/1000, 40'lı yaşlarda ise 1/100 siklıkta gözlenir (Coulam ve ark., 1986). POY'e neden olan üç faktör bulunmaktadır; (i) primordial follikül havuzunda azalma, (ii) folliküler atrezi oranında artma (iii) folliküler işlev veya olgunlaşmanın gerçekleşmemesi. Olguların çoğunun etiyolojisi bilinmemektedir. Bununla birlikte viral, otoimmun, çevresel toksinler, pelvik cerrahi, radyasyon veya kemoterapi gibi etkenler de POY'e neden olabilmektedir. Bazı genlerdeki (ATM, AIR, FSH reseptör, inhibin $\alpha$ geni ve FMR1 premutasyonu) mutasyonların da POY ile ilişkili olduğu bulunmuştur (Goswami ve Conway, 2005). Ayrica, X kromozom anomalileri de POY'e neden olmaktadir (The ESHRE Capri Workshop Group, 2008). Özellikle X kromozomunun uzun kolunda, iki kritik bölgenin Xq13-21 (Powel ve ark., 1994) ve Xq26-27 (Kraus ve ark., 1987) POY ile ilişkili olduğu saptanmıştır.

Bu olguda literatürü destekleyen Xq21 delesyonu ile POY arasındaki ilişki klinik ve genetik açıdan değerlendirilmiştir. 


\section{Olgu}

POY tanısıyla gelen kadın olgu, 22 yaşında, $150 \mathrm{~cm}$ boyunda olup boy kısalığı dışında fiziksel bulguları normaldi. İlk mens 16 yaşında ve bir yıl düzenli, sonraki yıllarda ise düzensizleşmiştir. Sekonder seks karakterleri gelişmiş olup pelvik ultrasonografide uterus pozisyonu retrovert, konturlar

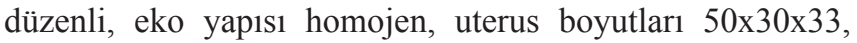
overler normal olup, sağ over $18 \times 11 \times 15$, sol over $22 \times 12 \times 17$ boyutlarındaydı. Endokrinolojik testler; serbest T3:3,64, T4:1,22, TSH:0,61 ile normaldi ve eşey hormonları serum değerleri FSH:76,89 $\mathrm{mlU} / \mathrm{ml}$, estradiol:25,59 $\mathrm{mlU} / \mathrm{ml}$, LH:39,69 $\mathrm{mlU} / \mathrm{ml}$, prolaktin:16,05 $\mathrm{mlU} / \mathrm{ml}$ olup ovaryen yetmezlik ile uyumluydu. Altı aylık evli olan olgu, orta öğretim almış ve sınavı kazanmasına rağmen üniversiteye gönderilmemiştir. Sekiz kız kardeşi ve 1 erkek kardeşi olan olgunun evli olan 7 kız kardeşinin hepsinin sağlıklı çocukları vardı. Akraba evliliği yapmış olan olgunun ebeveynlerine henüz ulaşılamadığı için kromozom analizleri yapılamadı. Sporadik POY olduğu düşünülen olgunun, konvansiyonel sitogenetik analizle, periferal kan lenfosit kültüründen, GTG bantlama ile yapılan incelemesinde $46, X, \operatorname{del}(\mathrm{X})(\mathrm{q} 21 \rightarrow \mathrm{qter})$ karyotipi gözlendi (Şek. 1).

\section{Tartışma}

$\mathrm{Bu}$ çalışmada Xq21 delesyonu gözlenen bir olgu, klinik ve genetik açıdan değerlendirilmiştir. $\mathrm{X}$ kromozom delesyonları ile POY arasındaki ilişki literatürde yaygın olarak verilmiştir (Goswami and Conway, 2005). Genellikle X kromozomundaki kırıların Xq13 ve Xq26 arasında yer aldığı gösterilmiştir. Rizzolia ve ark. (2006), 25 olgu üzerinde yaptıkları çalışmada, $\mathrm{X}$ otozom kromozomları arasındaki dengeli translokasyonlar ve delesyonların Xq13'den Xq27'ye kadar olan bölgede meydana geldiğini tespit etmişlerdir. Bizim olgumuzda olduğu gibi (Portnoi ve ark., 2006) POY'lu olan 90 hastanın 3'ünde Xq21 $\rightarrow$ qter delesyonu gözlemişlerdir.

POY fenotipine yol açan temel moleküler mekanizma,

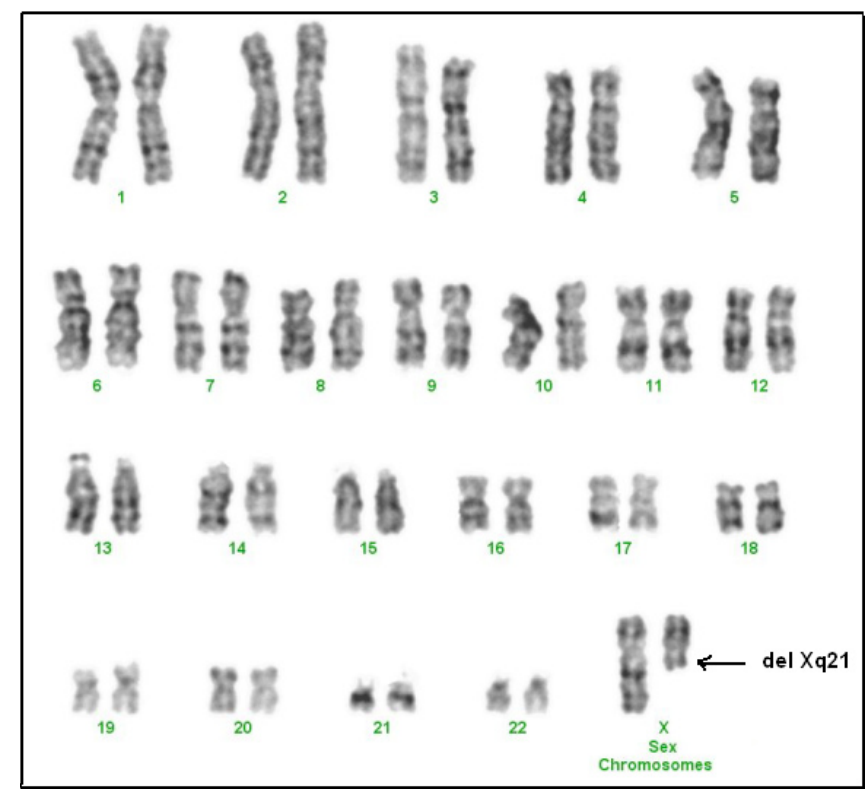

Şek. 1. Olgunun karyotipi; 46,X,del(X)(q21)

delesyonlu X'in inaktivasyondan kaçması ve delesyona uğrayan bölge içinde yer alan genlerin haplo-yetersizlik durumudur (Portnoi ve ark., 2006). POY'li hastaların çoğunda bizim olgumuzda olduğu gibi puberte sonrası dönemde ovaryen yetmezlik gözlenmektedir (Sontoro, 2003). Bu durum sekonder amenore ve follikül gelişiminin durması ile karakterizedir. FSH ve LH'ın yüksek oluşu ovaryen yetmezliği gösteren bir belirteçtir (Beck-Peccos and Persani, 2006). Olgumuz genetik danışmanlık açısından değerlendirildiğinde, boy kısalığı dışında fiziksel ve cinsiyet karakterleri normal, ancak sekonder amenore olmasi nedeniyle erken osteoporozun önlenmesi için eksik olan hormon tedavisinin yanısıra, erken gebelik veya oositlerinin toplanması ve korunması önerilebilir.

\section{KAYNAKLAR}

Beck-Peccos, P., Persani, L., 2006. Premature ovarian failure. Orphanet J. Rare Dis. 6, 1-9.

Coulam, C., Adamson, S.C., Annegers, J.F., 1987. Incidence of premature ovarian failure. Obstet. Gynecol. 67, $604-606$.

Goswami, D., Conway G.S., 2005. Premature ovarian failure. Hum. Reprod. Update. 11, 391-409.

Krauss, C., Turksoy, R.N., Atkins, L., McLaughlin, C., Brown, L.G., Page, D.C., 1987. Familial premature ovarian failure due to an interstitial deletion of the long arm of the X chromosome. New Engl. J. Med. 317, 125-131.

Portno1, M.F., Aboura, A., Tachdjian, G., Bouchard, P., Dewailly, D., Bourcigaux, N., Frydman, R., Reyss, A.C., Brisset, S., Christin-Maitre, S., 2006. Molecular cytogenetic studies of Xq critical regions in premature ovarian failure patients. Hum. Reprod. 21, 2329-2334.

Powell, C.M., Taggart, R.T., Drumheller, T.C., Wangsa, D., Qian, C., Nelson, L.M. White, B.J., 1994. Molecular and cytogenetic studies of an X; autosome translocation in a patient with premature ovarian failure and review of the literature. Am. J. Med. Genet. 52, 19-26.

Rizzolio, F., Bione, S., Sala, C., Goegan, M., Gentile, M., Gregato, G., Rossi, E., Pramparo, T., Zuffardi, O., Toniolo, D., 2006. Chromosomal rearrangements in Xq and premature ovarian failure: Mapping of 25 new cases and review of the literature. Hum. Reprod. 21, $1477-1483$.

Santoro, N., 2003. Mechanisms of premature ovarian failure. Am. Endocrinol. 64, 87-92.

The ESHRE Capri Workshop Group. Genetik aspect of female reproduction. 2008. Hum. Reprod. Update. 14, $293-307$.

Vegetti, W., Marozzi, A., Manfredini, E., Testa, G., Alagna, F., Nicolosi, A., Caliari, I., Taborelli, M., Tibiletti, M.G., Dalpra, L., Crosignani, P.G., 2000. Premature ovarian failure. Mol. Cell Endocrinol. 161, 53-57. 